\title{
PERAN EKSPRESI p53 DAN SURVIVIN TERHADAP HEMOGLOBIN, LEUKOSIT, DAN TROMBOSIT PADA LEUKEMIA LIMFOBLASTIK AKUT ANAK YANG MENDAPATKAN KEMOTERAPI
}

\author{
Candy Maharani Wairo ${ }^{\star \bowtie}$, Susanto Nugroho*, Hidayat Suyuti ${ }^{* * *}$
}

\begin{abstract}
Abstrak
Leukemia limfoblastik akut (LLA) merupakan jenis leukemia paling sering ditemukan (97\%) dan menjadi penyebab kematian anak. Terapi sitostatika dapat mengakibatkan kerusakan DNA yang memicu apoptosis dengan cara menstimulasi p53 sebagai proapoptosis, menghambat survivin sebagai antiapoptosis yang berperan dalam perbaikan kadar hemoglobin, jumlah leukosit dan trombosit. Penelitian ini ingin mengungkap peran ekspresi p53 dan survivin terhadap kadar hemoglobin, leukosit, trombosit pada LLA anak yang mendapat kemoterapi. Studi kohort prospektif dilakukan di ruang rawat inap anak RS. Dr. Saiful Anwar Malang, pada bulan April-Juni 2018. Populasi penderita LLA berdasarkan analisis morfologi darah perifer dan aspirasi bone marrow. Deteksi ekspresi p53 dan survivinn menggunakan metode flow cytometry. Analisis statistik menunjukkan ekspresi $p 53$ meningkat $(p=0,003)$, ekspresi survivin menurun $(p=0,000)$, hemoglobin $(p=0,039)$, leukosit $(p=0,000)$, trombosit $(p=0,023)$ meningkat. Setelah dilakukan kemoterapi, didapatkan hubungan ekspresi $p 53$ dengan hemoglobin $(p=0,873)$, leukosit $(p=0,212)$, dan trombosit $(p=$ $0,670)$ tidak signifikan. Hubungan ekspresi survivin dengan hemoglobin $(p=0,682)$, leukosit $(p=0,907)$, trombosit $(p=0,936)$ setelah dilakukan kemoterapi tidak signifikan. Hubungan $p 53$ dan survivin pada pasien LLA anak sebelum kemoterapi $(p=0,005)$ signifikan, namun sesudah kemoterapi $(p=0,467)$ tidak signifikan. Dapat disimpulkan bahwa kemoterapi meningkatkan ekspresi p53, menurunkan ekspresi survivin, dan meningkatkan kadar hemoglobin, leukosit, trombosit. Ada hubungan yang tidak signifikan antara p53 dan survivin terhadap kadar hemoglobin, leukosit, trombosit, sebelum dan sesudah kemoterapi. Didapatkan hubungan signifikan antara p53 dan survivin sebelum kemoterapi, namun tidak signifikan sesudah kemoterapi.
\end{abstract}

Kata kunci : leukemia limfoblastik akut, p53, survivin.

\section{ROLE OF p53 AND SURVIVIN EXPRESSIONS ON HEMOGLOBIN, LEUKOCYTES, AND THROMBOCYTES IN ACUTE LYMPHOBLASTIC LEUKEMIA CHILDREN WHO GET CHEMOTHERAPY}

\begin{abstract}
Acute lymphoblastic leukemia (ALL) is the most common type of leukemia (97\%) and the cause of child mortality. Cytostatic therapy can cause DNA damage that can trigger apoptosis by stimulating p53 as proapoptosis, inhibiting survivin as antiapoptosis which plays a role in improving hemoglobin, leukocyte, and thrombocytes. The research aim is to reveal the role of p53 and survivin expression on hemoglobin, leukocyte, thrombocytes in ALL children after chemotherapy. This prospective cohort study was conducted in a pediatric patient room of Dr. Saiful Anwar Hospital Malang on April-June 2018. Population with ALL was based on peripheral blood morphology analysis and bone marrow aspiration. The expression of p53 and surviving were detected by using flow cytometry. Statistical analysis showed that $p 53$ expression $(p=0.003)$ was increased, survivin expression $(p=0.000)$ was decreased, hemoglobin $(p=0.039)$, leukocytes $(p=$ 0.000 ), thrombocytes $(p=0.023)$ were increased. This conclude, the relation of $p 53$ expression with hemoglobin $(p=0.873)$, leukocyte $(p=0.212)$, and thrombocytes $(p=0.670)$ after chemotherapy was not significant. The relationship between survivin expression with hemoglobin $(p=0.682)$, leukocyte $(p=0.907)$, and thrombocytes $(p=0.936)$ after chemotherapy was not significant. The relationship between $p 53$ and survivin in children of ALL patients before chemotherapy $(p=0.005)$ was significant, but it was not significant after chemotherapy $(p=0.467)$. To conclude, the expression of $p 53$ was increasing after chemotherapy and the expression of survivin was decreased, and the concentration of hemoglobin, leukocytes, and
\end{abstract}

E-mail: candymaharani97@gmail.com 
thrombocytes was increased. There was no significant relationship between p53 and survivin on hemoglobin, leukocytes, and thrombocytes. There was a significant relationship between p53 and survivin before chemotherapy, but not significant after chemotherapy.

Keywords: acute lymphoblastic leukemia, p53, survivin.

*Program Studi Magister IImu Biomedik, Fakultas Kedokteran, Universitas Brawijaya

${ }^{* *}$ Departemen IImu Kesehatan Anak, Fakultas Kedokteran, Universitas Brawijaya

${ }^{* * *}$ Departemen Biokimia-Biomolekuler, Fakultas Kedokteran, Universitas Brawijaya

\section{Pendahuluan}

Salah satu jenis leukemia yang paling sering ditemukan (97\%) dengan insiden sebesar 4-4,5 kasus/100.000 anak/tahun adalah leukemia limfoblastik akut (LLA). Sebelum kemoterapi ditemukan, rata-rata usia harapan hidup leukemia hanya 3 bulan. Meskipun telah mencapai kemajuan pada dua dekade terakhir, sebanyak 20-25\% anak dengan LLA yang diterapi masih mengalami relaps dan resisten terhadap obat kemoterapi, dengan prognosis yang buruk dan menjadi penyebab kematian pada anak usia 1 hingga 15 tahun. ${ }^{1,2}$

Pemeriksaan laboratorium awal yang harus dikerjakan untuk mendeteksi LLA adalah anamnesa, data klinis, pemeriksaan darah lengkap dan hapusan darah tepi. Perubahan parameter hematologi pada pemeriksaan darah lengkap dapat beragam, mempengaruhi satu, dua, atau ketiga garis keturunan sel, yang tampak sebagai leukopenia atau leukocytosis dengan neutropenia, anemia, dan trombositopenia. ${ }^{3}$

Sebuah penelitian menjelaskan mekanisme yang berperan pada leukemia telah diidentifikasi sebagai proses apoptosis sel yang tidak adekuat. Apoptosis yang berlebihan terkait dengan suatu kondisi degeneratif, sebaliknya defisiensi apoptosis memicu autoimunitas dan kanker termasuk leukemia pada anak. ${ }^{4}$

Gangguan apoptosis tidak hanya memberikan kontribusi untuk terbentuknya tumor, tetapi dapat dikaitkan dengan perkembangan resistensi kemoterapi. Oleh karena itu, pemahaman yang baik dan penelitian tentang mekanisme apoptosis pada pasien leukemia dapat memberikan kesempatan untuk memodulasi jalur ini dengan meningkatkan efektivitas kemoterapi. $^{2}$

Salah satu penelitian hematologi menunjukkan p53 sebagai supresor tumor yang akan memantau stres selular dengan menginduksi apoptosis yang diperlukan dalam jaringan, sedangkan stressor menghasilkan kerusakan parah dan tidak dapat diperbaiki, dan p53 dapat memulai apoptosis, sehingga dapat menghilangkan sel yang rusak. ${ }^{5}$ Protein antiapoptosis yang dapat menghambat apoptosis adalah survivin. ${ }^{6}$ Overekspresi survivin ditemukan berkorelasi dengan prognosis buruk dalam berbagai kanker termasuk keganasan hematologi. ${ }^{7}$ Children Oncology Group melaporkan bahwa terdapat perbedaan profil ekspresi pada pasien leukemia relaps dengan diagnosis awal. Hal tersebut berdasarkan pada ekspresi protein penanda yang meningkat yaitu survivin yang menjadi target terapi karena ekspresinya terdeteksi saat perkembangan keganasan. Peningkatan ekspresi survivin pada berbagai malignansi berkorelasi dengan kejadian relaps dan kegagalan terapi, serta rendahnya harapan hidup pasien leukemia. ${ }^{8}$ Berdasarkan teori patofisiologisnya, terdapat hubungan antara ekspresi p53 protein proapoptosis yang berperan penting sebagai supresor tumor, dan survivin sebagai inhibitor apoptosis terhadap kadar hemoglobin, leukosit, dan trombosit pada pasien leukemia limfoblastik akut anak sesudah kemoterapi fase induksi. ${ }^{9}$ 
Berdasarkan penjelasan di atas peneliti ingin membuktikan peran ekspresi p53 dan survivin terhadap kadar hemoglobin, jumlah leukosit dan jumlah trombosit pada pasien Leukemia limfoblastik akut anak yang mendapatkan kemoterapi. Hasil penelitian ini diharapkan dapat dijadikan bahan acuan menilai parameter respons kemoterapi terhadap luaran klinis dengan melihat parameter laboratorium pasien LLA anak yang mendapatkan kemoterapi fase induksi.

\section{Bahan dan Metode}

\section{Desain dan Subjek Penelitian}

Penelitian kohort prospektif ini dilakukan di ruang anak RSUD. Dr. Saiful Anwar dan Laboratorium Biomedik Fakultas Kedokteran Universitas Brawijaya Malang, pada bulan April-Juni 2018. Populasi penelitian adalah penderita LLA dengan kriteria diagnosis berdasarkan analisis morfologi darah perifer dan aspirasi sumsum tulang. Total sampel sebanyak 11. Kriteria inklusi yaitu pasien terdiagnosis leukemia limfoblastik akut, mendapatkan kemoterapi fase induksi, usia 1-10 tahun, keluarga penderita mengizinkan anaknya diikutsertakan dalam penelitian. Kriteria eksklusi yaitu penderita drop Out selama fase induksi kemoterapi. Penelitian ini telah mendapat persetujuan etik dari Komisi Etik Penelitian Kesehatan RSUD. Dr. Saiful Anwar dengan nomor surat: 400/137/K.3/302/2018.

\section{Definisi Operasional}

Definisi operasional untuk diagnosis LLA ditegakkan dengan anamnesis, pemeriksaan fisik, dan pemeriksaan aspirasi sumsum tulang didapatkan sedikitnya $30 \%$ sel muda (blast) dan positif dengan immunophenotyping LLA. Kemoterapi fase induksi yang dilaksanakan berdasarkan protokol ALL Indonesian 2011 High Risk yang direvisi 2013. Ekspresi p53 adalah Jumlah p53 pada sel mononuclear dalam satuan persen (\%) yang dianalisis menggunakan flow cytometry. Ekspresi survivin adalah jumlah survivin pada sel mononuklear dalam satuan persen (\%) yang dianalisis menggunakan flow cytometry dengan antibodi monoklonal survivin. $\mathrm{Hb}$ adalah besaran yang menunjukkan banyaknya hemoglobin yang terkandung dalam setiap satuan volume darah, satuan angka hemoglobin darah adalah gram/deciliter ( $g / d L)$. Leukosit adalah sel darah putih yang membentuk komponen darah, berfungsi sebagai bagian sistem kekebalan tubuh, satuan angka leukosit adalah sel/microliter (sel/ $\mu \mathrm{L})$. Trombosit adalah jumlah trombosit darah tiap satuan volume darah, angka trombosit darah dinyatakan dalam ribu platelet per microliter (ribu platelet/ $\mu \mathrm{L}$ ).

Isolasi Peripheral Blood Mononuclear Cell (PBMC)

Isolasi PBMC terdiri dari: Darah segar dengan EDTA, phosphate buffer saline (PBS), Ficoll-Hypaque solution (densitas1.077 g/mL), 15- atau 50-ml conical centrifuge tubes. Isolasi peripheral blood mononuclear cells (PBMC) menggunakan ficoll hypaquedensity gradient centrifugation, metode yang mudah dan cepat untuk memperoleh PBMC murni dengan cara didapatkan perbedaan densitas antara PBMC dengan komponen darah lainnya. Darah tepi merupakan sumber sel limfosit untuk penelitian sistem imun pada manusia. Sel mononuclear dan trombosit akan terkumpul di lapisan atas pada FicollHypaque karena densitasnya yang rendah, sedangkan eritrosit dan granulosit dengan densitasnya yang tinggi akan terkumpul di lapisan bawah. Lapisan atas (berisi plasma dan sebagian besar trombosit) dipindahkan dengan menggunakan pipet steril. Dengan menggunakan pipet yang lain lapisan yang terdapat sel mononuclear (cincin buffy coat) dipindahkan secara hati-hati ke tabung sentrifuse yang lain. Sel yang akan diperiksa 
dicuci dengan menambahkan PBS (3x dari volume lapisan sel mononuclear) dan disentrifuse selama 10 menit dengan kecepatan $400 \mathrm{~g}$. Supernatan dibuang dan pellet dicuci sekali lagi. Terhadap pellet yang terbentuk, dilakukan pemeriksaan flowcytometry untuk mengukur ekspresi p53 dan ekspresi survivin.

Deteksi Ekspresi p53 dan Survivin dengan Metode Flow Cytometry

Sampel darah-EDTA sebanyak $3 \mathrm{cc}$ diambil dari pasien untuk diisolasi PBMC dan dideteksi ekspresi p53 dan survivin dengan flow cytometry. Pemeriksaan flow cytometry terdiri dari: homogenat, FITC antihuman p53 antibody for flow cytometry (katalog number sc7272 FITC, Santacruz), $P E$ anti-human survivin antibody for flow cytometry (katalog number IC6472P, RnD systems), cell staining buffer (katalog number 420201, BioLegend), fixation buffer (katalog number 420801, BioLegend), permeabilitazion wash buffer (katalog number 421002, BioLegend), flow cytometry dan deplesi sel pengkontaminasi fraksi mononuclear. Semua sampel penelitian sebelum dan sesudah menjalani kemoterapi fase induksi, diambil sampel darahnya sebanyak $3,5 \mathrm{ml}$, pengambilan $0,5 \mathrm{ml}$ untuk pemeriksaan darah lengkap sesuai protap/syarat sebelum dan sesudah kemoterapi fase induksi di RS. Dr. Saiful Anwar dan $3 \mathrm{ml}$ disimpan dalam tabung EDTA dan dipertahankan suhunya $4{ }^{\circ} \mathrm{C}$ dalam cool box dikirim segera ke laboratorium Biomedik Fakultas Kedokteran Universitas Brawijaya untuk pemeriksaan flow cytometry. Preparasi sampel dilakukan sesuai prosedur. Program mesin flowcytometry diatur sesuai parameter yang ingin dianalisis, meliputi banyaknya jumlah sel, label antibodi yang digunakan, dan nama sampel. Selanjutnya sampel dianalisis menggunakan software BD Cell Quest Pro.
Teknik Analisis Statistik

Analisis data pada penelitian ini dilakukan dalam beberapa tahap: 1 . Uji normalitas data sampel untuk menentukan jenis analisis yang tepat digunakan selanjutnya, 2. Uji komparasi, 3. Uji korelasi dan diolah menggunakan SPSS for wimdows. ${ }^{10}$

Hasil

Terdapat 5 variabel karakteristik subjek penelitian yang diamati yaitu jenis kelamin, usia, tipe LLA, hasil kemoterapi fase induksi, dan parameter laboratorium (Tabel 1). Berdasarkan data karakteristik subjek didapatkan jenis kelamin laki-laki $4(36,4 \%)$ dan perempuan 7 (63,6\%). Usia median 6 tahun (1-10 tahun), tipe LLA L1 sebanyak 2 $(18,2 \%)$ dan LLA L2 9 (81,8\%), hasil kemoterapi didapatkan remisi komplet 6 $(54,5 \%)$, remisi parsial $4(36,4 \%)$ dan tidak remisi 1 (9,1\%). Parameter laboratorium sebelum kemoterapi dengan nilai rerata hemoglobin 11,0, nilai leukosit 2908 dan trombosit 102.181.

Ekspresi P53 dan Survivin, Kadar Hemoglobin, Leukosit dan Trombosit pada LLA Anak Sebelum dan Sesudah Kemoterapi Fase Induksi

Pada Tabel 2 didapatkan peningkatan rata-rata persentase ekspresi p53 sesudah kemoterapi fase induksi $(p=0,003)$. Namun, terjadi penurunan rata-rata persentase survivin yang tinggi sesudah kemoterapi fase induksi $(p=0,000)$. Selain itu, didapatkan juga peningkatan rata-rata kadar hemoglobin $(p=0,039)$, leukosit $(p=0,000)$, trombosit ( $p$ $=0,023$ ) yang tinggi sesudah kemoterapi fase induksi. Hasil analisis flow cytometry untuk menentukan ekspresi p53 menggunakan FITC anti-human p53 antibody (Gambar 1) dan survivin menggunakan PE anti-human survivin antibody (Gambar 2). 
Hubungan Ekspresi p53 dengan Kadar Hemoglobin pada Pasien LLA Anak Sebelum dan Sesudah Kemoterapi Fase Induksi

Berdasarkan Tabel 3 didapatkan hubungan yang tidak signifikan antara ekspresi p53 dengan kadar hemoglobin sebelum kemoterapi $(p=0,968)$ dan setelah kemoterapi $(p=-0,055)$ fase induksi pada pasien LLA anak.
Hubungan Ekspresi Survivin dengan Kadar Hemoglobin pada Pasien LLA Anak Sebelum dan Sesudah Kemoterapi Fase Induksi

Berdasarkan Tabel 3 terdapat hubungan yang tidak signifikan antara ekspresi survivin dengan kadar hemoglobin sebelum $(p=0,802)$ dan setelah kemoterapi $(p=0,682)$ fase induksi pada pasien LLA anak.
A
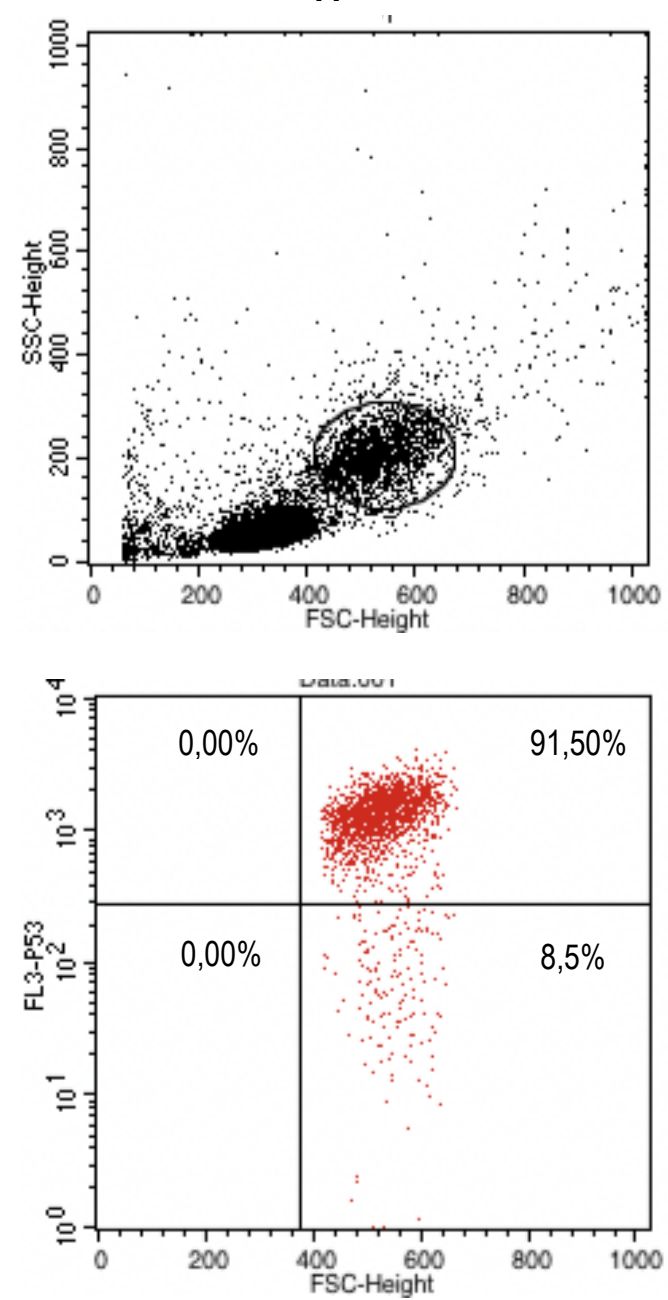

B
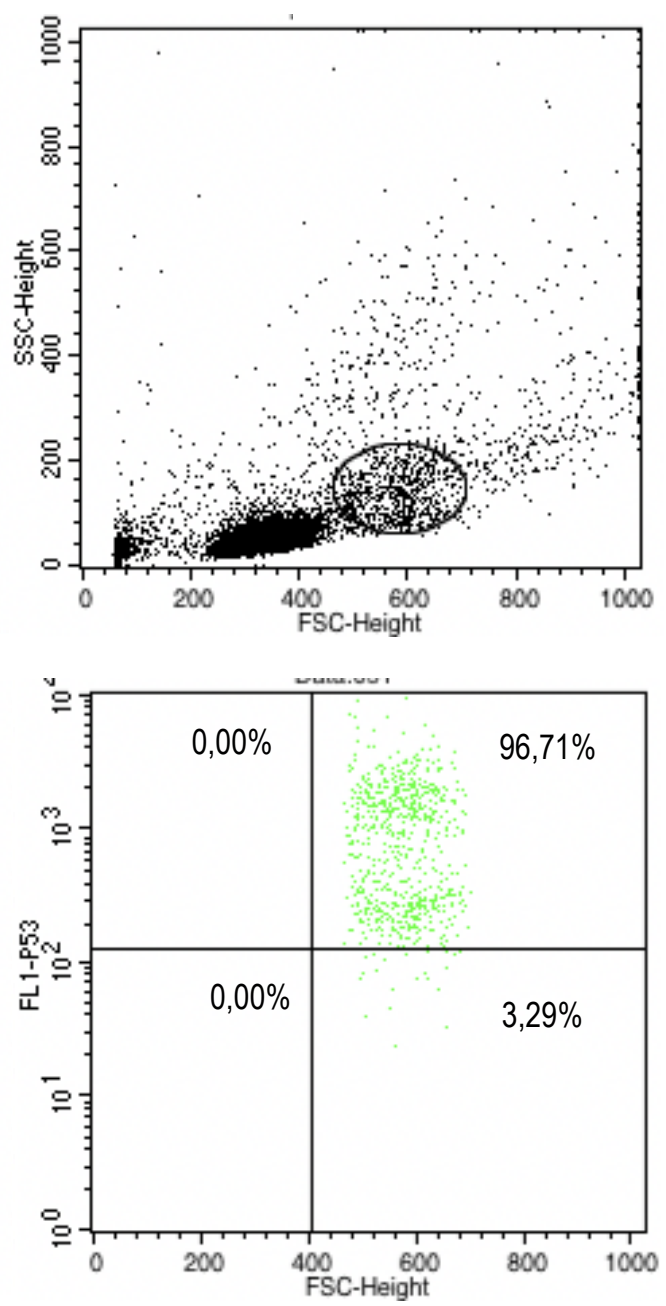

Gambar 1. Analisis flow cytometry untuk penentuan ekspresi p53 menggunakan FITC anti-human p53 antibody.

Keterangan : A. Sebelum kemoterapi fase induksi didapatkan ekspresi p53 \% gated $=91,50 \%$, B. Setelah kemoterapi fase induksi didapatkan ekspresi p53 $\%$ gated $=96,71 \%$. 
A
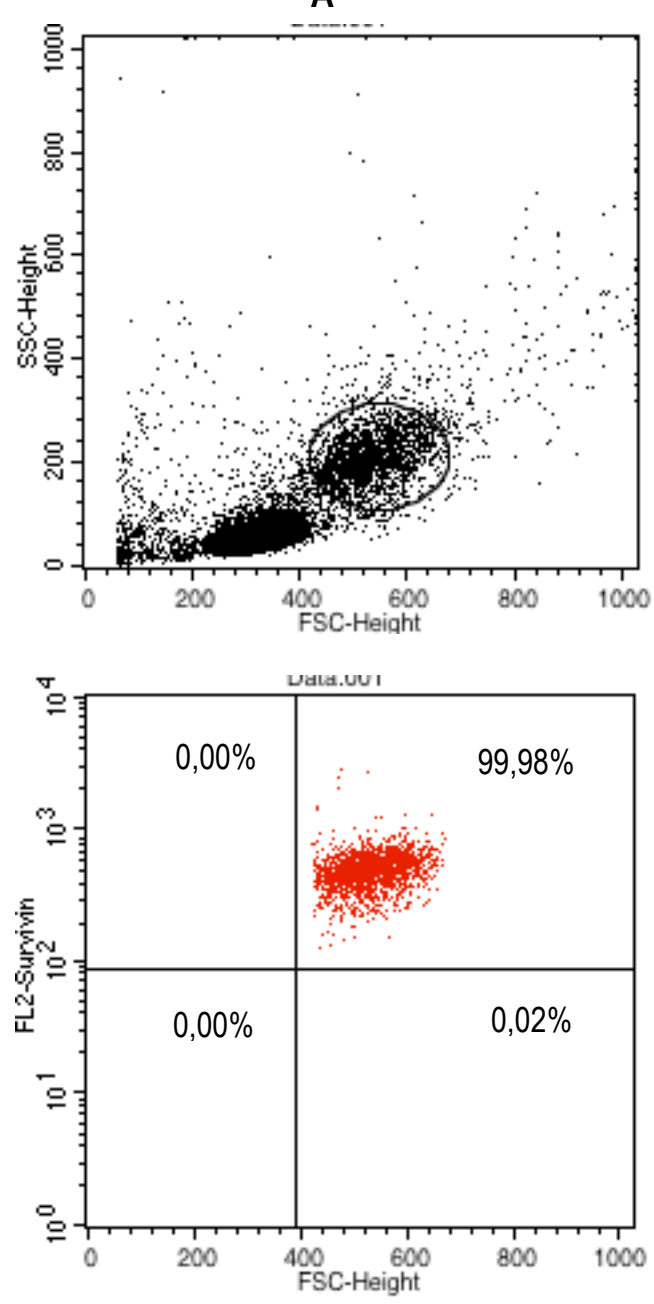

B
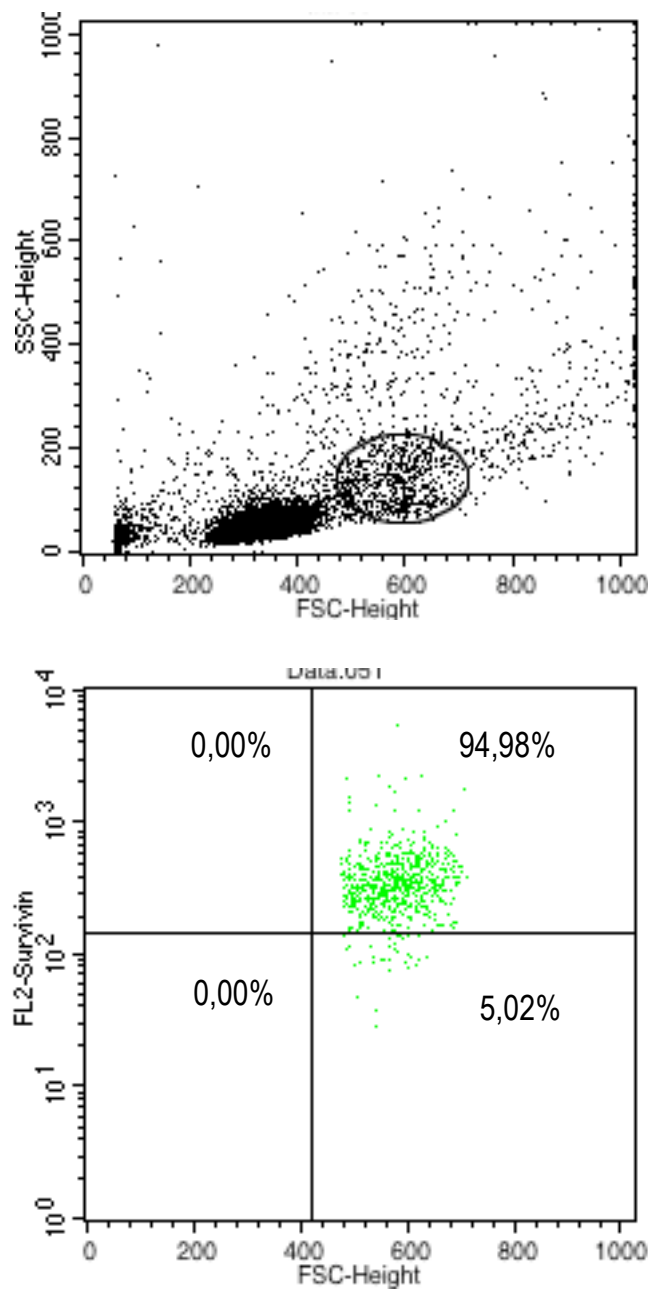

Gambar 1. Analisis flow cytometry untuk penentuan ekspresi survivin menggunakan PE antihuman survivin antibody.

Keterangan : A. Sebelum kemoterapi fase induksi didapatkan ekspresi surviving $\%$ gated $=99,98 \%$, B. Setelah kemoterapi fase induksi didapatkan ekspresi survivin $\%$ gated $=94,98 \%$. 
Hubungan Ekspresi p53 dengan Kadar Leukosit Sebelum dan Sesudah Kemoterapi Fase Induksi

Pada Tabel 4 didapatkan hubungan yang tidak signifikan antara ekspresi p53 dengan kadar leukosit sebelum $(p=0,631)$ dan setelah kemoterapi $(p=0,212)$ fase induksi pada pasien LLA anak.

Hubungan Ekspresi Survivin dengan Kadar Leukosit Sebelum dan Sesudah Kemoterapi Fase Induksi

Pada Tabel 4 didapatkan hubungan yang tidak signifikan antara ekspresi survivin dengan jumlah leukosit sebelum ( $p=$ $0,894)$ dan setelah kemoterapi $(p=0,907)$ fase induksi pada pasien LLA anak.

Hubungan Ekspresi p53 dengan Kadar Trombosit Sebelum dan Sesudah Kemoterapi Fase Induksi

Berdasarkan Tabel 5 didapatkan hubungan yang tidak signifikan antara ekspresi p53 dengan trombosit sebelum $(p=$
$0,545)$ dan setelah kemoterapi $(p=0,670)$ fase induksi pada pasien LLA anak.

Hubungan Ekspresi Survivin dengan Kadar Trombosit Sebelum dan Sesudah Kemoterapi Fase Induksi

Pada Tabel 5 diketahui adanya hubungan yang tidak signifikan antara ekspresi survivin dengan kadar trombosit sebelum $(p=0,088)$ dan setelah kemoterapi $(p=0,936)$ fase induksi pada pasien LLA anak.

Hubungan Ekspresi p53 dengan Ekspresi Survivin pada Pasien LLA Anak Sebelum dan Sesudah Kemoterapi Fase Induksi

Berdasarkan Tabel 6 didapatkan hubungan yang signifikan antara ekspresi survivin dengan ekspresi p53 sebelum kemoterapi $(p=0,005)$, namun hubungan antara ekspresi survivin dengan ekspresi p53 sesudah kemoterapi tidak signifikan ( $p=$ $0,467)$.

Tabel 1. Karakteristik subjek penelitian.

\begin{tabular}{l|c}
\hline \multicolumn{1}{c|}{ Karakteristik Subjek } & Nilai \\
\hline Jenis Kelamin & $\mathrm{n}(\%)$ \\
\hline Laki-laki & $4(36,4)$ \\
Perempuan & $7(63,6)$ \\
\hline Usia (tahun) median (min-max) & $6(1-10)$ \\
\hline Tipe LLA & $\mathrm{n}(\%)$ \\
\hline LLA L1 & $2(18,2)$ \\
LLA L2 & $9(81,8)$ \\
\hline Hasil kemoterapi fase induksi & $\mathrm{n}(\%)$ \\
\hline Remisi komplet & $6(54,5)$ \\
Remisi parsial & $4(36,4)$ \\
Tidak remisi & $1(9,1)$ \\
\hline Parameter laboratorium & $(\mathrm{rerata})$ \\
Hemoglobin & $11,0(\mathrm{~g} / \mathrm{dL})$ \\
Leukosit & $2.908(\mathrm{sel} / / \mathrm{LL})$ \\
Trombosit & $102.181(\mathrm{ribu} \mathrm{platelet/ \mu L)}$ \\
\hline
\end{tabular}


Tabel 2. Ekspresi p53, ekspresi survivin, kadar hemoglobin, leukosit, dan trombosit sebelum dan sesudah kemoterapi fase induksi.

\begin{tabular}{llll}
\hline Variabel & Sebelum kemoterapi & sesudah kemoterapi & $p$-value \\
\hline Ekspresi p53 & $71,5 \pm 33,2(\%)$ & $76,7 \pm 32,2(\%)$ & 0,003 \\
Ekspresi survivin & $98,2 \pm 1,6(\%)$ & $92,5 \pm 1,6(\%)$ & 0,000 \\
Hemoglobin & $11,0 \pm 1,4(\mathrm{~g} / \mathrm{dL})$ & $11,9 \pm 1,0(\mathrm{~g} / \mathrm{dL})$ & 0,039 \\
Leukosit & $2.908 \pm 994(\mathrm{sel} / \mu \mathrm{L})$ & $8.938 \pm 2.486(\mathrm{sel} / \mu \mathrm{L})$ & 0,000 \\
Trombosit & $102.181 \pm 91.509($ ribu platelet $/ \mu \mathrm{L})$ & $224.272 \pm 113.731($ ribu platelet $/ \mu \mathrm{L})$ & 0,023 \\
\hline
\end{tabular}

Tabel 3. Hubungan ekspresi p53, ekspresi survivin dengan kadar hemoglobin sebelum dan sesudah kemoterapi fase induksi.

\begin{tabular}{ccccc}
\hline \multirow{2}{*}{ Kelompok } & \multicolumn{2}{c}{ ekspresi p53 dengan kadar $\mathrm{Hb}$} & \multicolumn{2}{c}{ ekspresi survivin dengan kadar $\mathrm{Hb}$} \\
\cline { 2 - 5 } & koefisien korelasi $(\mathrm{r})$ & $p$ value & koefisien korelasi $(\mathrm{r})$ & $p$ value \\
\hline Sebelum kemoterapi & 0,014 & 0,968 & $-0,086$ & 0,802 \\
Sesudah kemoterapi & $-0,055$ & 0,873 & $-0,140$ & 0,682 \\
\hline
\end{tabular}

Tabel 4. Hubungan ekspresi p53 dan ekspresi survivin dengan kadar leukosit sebelum dan sesudah kemoterapi fase induksi.

\begin{tabular}{ccccc}
\hline & \multicolumn{2}{c}{ Ekspresi p53 dengan leukosit } & \multicolumn{2}{c}{ Ekspresi survivin dengan leukosit } \\
\cline { 2 - 5 } & koefisien korelasi $(r)$ & $p$ value & koefisien korelasi $(r)$ & $p$ value \\
\hline Sebelum kemoterapi & 0,164 & 0,631 & 0,046 & 0,894 \\
Setelah kemoterapi & $-0,409$ & 0,212 & 0,040 & 0,907 \\
\hline
\end{tabular}

Tabel 5 . Hubungan ekspresi p53 dan ekspresi survivin dengan kadar trombosit sebelum dan sesudah kemoterapi fase induksi.

\begin{tabular}{ccccc}
\hline \multirow{2}{*}{ Kelompok } & \multicolumn{2}{c}{ Ekspresi p53 dengan trombosit } & \multicolumn{2}{c}{ Ekspresi survivin dan trombosit } \\
\cline { 2 - 5 } & koefisien korelasi $(r)$ & $p$ value & koefisien korelasi $(r)$ & $p$ value \\
\hline Sebelum kemoterapi & 0,205 & 0,545 & 0,538 & 0,088 \\
Setelah kemoterapi & $-0,145$ & 0,670 & $-0,027$ & 0,936 \\
\hline
\end{tabular}

Tabel 6. Hubungan ekspresi p53 dengan ekspresi survivin sebelum dan sesudah kemoterapi fase induksi.

\begin{tabular}{ccc}
\hline \multirow{2}{*}{ Kelompok } & \multicolumn{2}{c}{ Ekspresi p53 dan survivin } \\
\cline { 2 - 3 } & koefisien korelasi $(r)$ & $p$ value \\
\hline Sebelum kemoterapi & 0,773 & 0,005 \\
Setelah kemoterapi & 0,245 & 0,467 \\
\hline
\end{tabular}




\section{Pembahasan}

Pada penelitian ini didapatkan responden berjenis kelamin laki-laki sebanyak $4(36,3 \%)$ pasien dan perempuan $9(63,7 \%)$ pasien dengan median usia 6 tahun. Data ini bertolak belakang dengan penelitian yang menunjukkan rasio $1,4: 1$ menyatakan bahwa jenis kelamin didominasi laki-laki dari 196 anak didapatkan $79 \%$ anak berusia 1-10 tahun, terbanyak usia 3,05 tahun. ${ }^{11}$

Deteksi ekspresi p53 dengan flow cytometry menunjukkan bahwa ekspresi p53 lebih tinggi pada penderita LLA sesudah kemoterapi fase induksi dibandingkan sebelum kemoterapi $(p=0,003)$. Pasien LLA anak mempunyai gejala klasik leukemia dengan gejala dan tanda yang berhubungan dengan infiltrasi sumsum tulang oleh sel leukemia yang menimbukan demam, pucat, lemah, perdarahan bawah kulit dan perdarahan mukosa, nyeri tulang, anoreksia dan kehilangan berat badan. Nilai leukosit merupakan salah satu prediktor untuk melihat prognosis pasien LLA. Jumlah leukosit awal saat diagnosis ditegakkan merupakan faktor prognosis yang bermakna tinggi. Ada hubungan linear antara kadar leukosit $50.000 / \mu \mathrm{l}$ yang mempunyai prognosis buruk. ${ }^{12}$

Protein p53 merupakan supresor tumor yang bertindak dalam menanggapi berbagai bentuk stres selular untuk memediasi berbagai proses antiproliferatif. Oleh karena itu, p53 dapat diaktifkan oleh kerusakan DNA, hipoksia, atau ekspresi onkogen menyimpang yang mendorong perubahan siklus sel, perbaikan DNA, penuaan selular, dan apoptosis. Sebagai akibatnya, gangguan fungsi p53 mendorong perubahan fungsi sel, ketidakstabilan genomik, dan pertumbuhan sel yang tidak tepat, yang memungkinkan proliferasi dan evolusi sel yang rusak. Aktivitas p53 harus diatur secara ketat, dengan produksi p53 terlalu banyak, atau terlalu sedikit akan memberikan kontribusi terhadap suatu penyakit. Selain perannya dalam menekan perkembangan tumor (tumorigenesis), apoptosis p53dependent memberikan kontribusi terhadap kematian sel yang diinduksi kemoterapi. Sesuai dengan peran potensial p53 pada modulasi kemoterapi kanker, hilangnya fungsi p53 dikaitkan dengan resistensi kemoterapi dalam jenis tumor tertentu. p53 berfungsi sebagai pengatur proses apoptosis yang dapat memodulasi titik kontrol pada jalur ekstrinsik dan intrinsik. Dua jalur dalam aktivasi p53 adalah jalur ARF-Mdm2-p53 akibat respons terhadap stres onkogenik dan jalur ATM-ATR-p53 akibat respons terhadap kerusakan DNA. ${ }^{13}$

Survivin merupakan molekul inhibitor apoptosis yang meningkat ekspresinya pada kejadian kelainan darah, salah satunya pada kasus LLA. Dengan adanya peningkatan survivin, apoptosis yang seharusnya terjadi pada sel-sel dengan kelainan genetik tidak terjadi sehingga menimbulkan pertumbuhan sel yang tidak terkontrol, yaitu perkembangan sel kanker tersebut. Pemberian kemoterapi dapat menurunkan ekspresi survivin dari berbagai jalur sehingga menghambat pertumbuhan dan perkembangan sel kanker. ${ }^{14}$

Penelitian ini menunjukkan penurunan ekspresi survivin setelah pemberian kemoterapi fase induksi dibandingkan dengan sebelum pemberian kemoterapi. Huang et al, 2015 meneliti pengaruh inhibisi ekspresi survivin melalui inhibitor transkripsi survivin YM155 yang dibandingkan dengan kemoterapi saja atau dikombinasikan keduanya. Meskipun meneliti secara in vitro dan penyakit yang berbeda yaitu leukemia myeloid akut, namun membuktikan bahwa kemoterapi saja menurunkan tingkat ketahanan sel kanker. Tingkat ketahanan sel yang menurun dapat diasumsikan sebagai peningkatan apoptosis yang dapat berkorelasi dengan penurunan ekspresi survivin. ${ }^{15}$ 
Rendahnya nilai hemoglobin baik disebabkan karena adanya supresi sumsum tulang akibat proliferasi sel kanker, maupun karena adanya perdarahan akibat rendahnya trombosit sangat berpengaruh terhadap prognosis pasien. Penundaan pemberian kemoterapi akan berdampak pada overekspresi dari sel ganas, dan proliferasi multi organ. Pasien dengan hemoglobin dan trombosit rendah memerlukan koreksi sebelum diberikan obat kemoterapi. ${ }^{16}$

Pada penelitian Jiang et al. (2015) disebutkan bahwa pemberian kemoterapi akan menurunkan jumlah sel blas dalam 14 hari, disertai dengan peningkatan jumlah leukosit pada pemeriksaan darah perifer. Pemeriksaan leukosit dan peningkatan ANC dapat memprediksi remisi komplet. Dalam penelitian ini leukosit berbanding lurus dengan ekspresi p53. Terdapat dua subjek penelitian dengan jumlah leukosit $>50000 u$, satu pasien mengalami keadaan hiperleukositosis yang merupakan salah satu kegawatan dalam bidang onkologi anak. Setelah mendapatkan kemoterapi fase induksi tidak didapatkan peningkatan leukosit, sebanyak 8 subjek didapatkan dengan leukopeni. Salah satu marker prognostik buruk pada LLA adalah meningkatnya leukosit/ hiperleukositosis. Salah satu penyebab tingginya angka relaps, baik relaps disumsum tulang maupun diluar sumsum tulang dan rendahnya survival rate penderita leukemia akut. ${ }^{15}$

Prediksi terjadinya kemoresistensi menjadi perhatian yang penting dan pemantauan pada pasien LLA. Terdapat hubungan antara prognosis yang buruk dan adanya sel blast pada 10 hari setelah kemoterapi fase induksi yang telah banyak dipahami para klinisi sebagai dasar untuk memulai reinduksi. Perbaikan platelet, trombopoetin, trombositosis merupakan parameter laboratorium yang buruk yang berpengaruh pada klinis LLA. Penelitian ini menunjukkan adanya peningkatan rata-rata kadar trombosit sebelum dan sesudah kemoterapi. Didapatkan delapan subjek penelitian mengalami trombositopeni saat awal diagnosis, tiga subjek yang mengalami trombositopeni $<50000$ dan dua pasien memerlukan transfusi darah karena didapatkan klinis perdarahan. Sementara 3 pasien dengan kadar trombosit normal saat awal kemoterapi. Dengan hasil nilai trombosit mengalami perbaikan setelah pemberian kemoterapi fase induksi. ${ }^{18}$

Sebagian besar manifestasi klinis LLA mencerminkan akumulasi sel-sel limfoid yang ganas dan berdiferensiasi rendah di dalam sumsum tulang, darah perifer, dan, daerah extramedullar. Presentasi bisa tidak spesifik, dengan kombinasi gejala konstitusional dan tanda-tanda kegagalan sumsum tulang (anemia, trombositopenia, leukopenia). Gejala umum seperti demam, penurunan berat badan, mudah perdarahan atau memar, kelelahan, dyspnea dan infeksi. Keterlibatan daerah extramedullar biasanya terjadi dan dapat menyebabkan limfadenopati, splenomegali atau hepatomegali pada $20 \%$ pasien. ${ }^{19}$

Peningkatan hemoglobin sejalan dengan adanya perbaikan setelah kemoterapi fase induksi, melalui kemoterapi dapat menghilangkan sel ganas yang mengivasi sumsum tulang melalui jalur intrinsik yang berbasis pada apoptosis. Pada penelitian oleh Feng Jiang et al., selama kurun waktu 2004 hingga 2013 meneliti korelasi antara hasil BMP dengan pemeriksaan darah tepi, dari 200 subjek penelitian, 56 orang sesuai kriteria inklusi, tidak didapatkan perbaikan/korelasi antara penurunan sel blast di sumsum tulang dengan perbaikan sel darah tepi. ${ }^{17}$

Berdasarkan the National Cancer Institute (NCl)/Rome, pasien LLA diklasifikasikan atas dasar kelompok risiko biasa pada anak berusia 1-9,99 tahun dengan jumlah leukosit $<50.000 / \mu l$ dan kelompok risiko tinggi pada anak berusia $>10$ tahun dan/atau jumlah leukosit $>50.000 /$ ul . 
Telah diketahui bahwa leukosit yang meningkat pada pasien LLA merupakan hasil dari keganasan pada LLA. Setelah kemoterapi, akan didapatkan penurunan jumlah leukosit dan peningkatan kadar p53. Berbeda dengan pasien kanker yang lain, leukosit tidak terpengaruh oleh sel kanker, sehingga pada penelitian $\mathrm{Ha}$ et al. (2016) pasien yang mengalami aktivasi p53 memiliki hitung leukosit lebih rendah dibandingkan dengan pasien yang mengalami supresi. ${ }^{20}$

Pada penelitian lain, Apostolidis et al pada tahun 2012 secara khusus melihat peran p53 pada megakaryopoiesis dan fungsi platelet. Hasil penelitian tersebut menunjukkan bahwa penurunan kadar p53 dapat meningkatkan terjadinya megakaryopoiesis. ${ }^{19}$ Namun, penelitian ini menunjukkan bahwa waktu perdarahan yang dialami pada hewan coba tanpa protein p53 memanjang, yang berarti kemampuan hemostasis yang dimiliki oleh hewan coba tersebut terganggu. Apostolidis et al menunjukkan bahwa protein p53 berperan tidak hanya pada peningkatan megakaryopoiesis, namun juga fungsi hemostasis. ${ }^{19}$

Esh et al pada tahun 2011 melakukan penelitian mengenai survivin sebagai faktor prognostik pada 30 pasien LLA anak dan melihat apakah terdapat hubungan antara profil darah dengan survivin, dan penelitian oleh Zhang et al pada tahun 2015 yang meneliti 56 pasien LLA anak dengan hasil tidak ada hubungan yang signifikan antara kadar hemoglobin dan ekspresi survivin. Kadar hemoglobin dapat menurun akibat depresi sumsum tulang pada pasien dengan LLA. 2,20

\section{Kesimpulan}

Kesimpulan yang didapatkan adalah ekspresi p53 lebih tinggi dan ekspresi survivin lebih rendah pada LLA anak sesudah kemoterapi fase induksi. Terdapat perbedaan kadar hemoglobin, leukosit, dan trombosit pada LLA anak sebelum dan sesudah kemoterapi fase induksi. Tidak terdapat hubungan antara ekspresi p53 dan ekspresi survivin dengan kadar hemoglobin, leukosit, dan trombosit pada LLA anak yang mendapatkan kemoterapi. Terdapat korelasi antara ekspresi p53 dengan survivin pada pasien LLA anak sebelum kemoterapi fase induksi, namun tidak terdapat korelasi antara ekspresi p53 dengan survivin pada pasien LLA anak setelah kemoterapi fase induksi.

\section{Saran}

Diperlukan penelitian lanjutan untuk menilai rasio p53/survivin yang dapat digunakan sebagai parameter penilaian respons kemoterapi LLA anak. Diperlukan penelitian lanjutan untuk menganalisis jalur intrinsik yang lebih berperan pada apoptosis LLA. Diperlukan penelitian lanjutan untuk menilai ekspresi p53 sebagai supresor tumor dengan protein antiapoptosis lain seperti Mdm2, caspase-3 dan Bax/Bcl-2.

\section{Daftar Pustaka}

1. Tubergen DG, Blayer A. The Leukemia. In: Kliegman RM, Behrman RE, Jenson $\mathrm{HB}$, et al. Nelson Textbook of Pediatrics. Elsevier. 2007. 2116-17

2. Esh AM, Atfy M, Azizi NA, El Naggar $M M$, Khalil EE, et al. Prognostic Significance of Survivin in Pediatric Acute Lymphoblastic Leukemia. India J Hematol Blood Transfus. 2011; 27(1):18-25.

3. Ghavami S, Hashemi M, Ande SR, Yeganeh B, Xiao W, et al. Apoptosis and Cancer: Mutations Within Caspase Genes. J Med Genet. 2009; 46:497510.

4. Hastings CA, Torkildson JC, and Agrawal AK. Evaluation of the Child with a Suspected Malignancy. In: Hastings CA, Torkildson JC, \& Agrawal, 
A. K. Handbook of Pediatric Hematology and Oncology: Children's Hospital \& Research Center Oakland. John Wiley \& Sons, Ltd. 2012. P.122-132.

5. Dohi T, et al. Mitochondrial Survivin Inhibits Apoptosis and Promotes Tumorigenesis. J Clinical Investigation. 2004; 114(8):1117-1127.

6. Fulda S. Exploiting Apoptosis Pathways for the Treatment of Pediatric Cancers. Pediatr Blood Cancer. 2009; 53:53336.

7. Troeger A, Siepermann M, Escherich G, Meisel R, Willers R, et al. Survivin and Its Prognostic Significance in Pediatric Acute B-Cell Precursor Lymphoblastic Leukemia. Haematologica. 2007; 92(8):1043-50.

8. Carter BZ, Kornblau SM, Tsao T et al. Caspase-Independent Cell Death in AML: Caspase Inhibition In Vitro with Pan-Caspase Inhibitors or In Vivo by XIAP or Survivin Does Not Affect Cell Survival or Prognosis. Blood. 2003; 102:4179-4186.

9. Hutter JJ. Childhood Leukemia. Pediatrics in Review. 2010; 31:234-41.

10. Arikunto, Suharsimi. Metode Penelitian Ekonomi. Jakarta: UI Press. 2010.

11. Mulatsih S. Fusi Gen TEL-AML1, BCR$A B L$, E2A-PPBX1, dan MLL-AF4 Sebagai Faktor Prognosis Leukemia Limfoblastik Akut. Yogyakarta: Fakultas Kedokteran Universitas Gadjah Mada. 2009.

12. Permono B, Ugrasena I. Buku Ajar Hematologi-Onkologi Anak. Cetakan Keempat. Jakarta: Badan Penerbit IDAI. 2005.

13. Maximov GK and Maximov KG. The Role of p53 Tumor Suppresor Protein in Apoptosis and Cancerogenesis. Biotechnol and Biotechnol Eq. 2008; 22:24-37.

14. Chen X, Duan N, Zhang C, Zhang W. Survivin and Tumorigenesis: Molecular
Mechanisms and Therapeutic Strategies. J Cancer. 2016; 7(3): 314323.

15. Huang J, Lyu H, Wang J, Liu B. Influence of Survivin-Targeted Therapy on Chemosensitivity in the Treatment of Acute Myeloid Leukemia. Cancer Lett. 2015; 366(2):160-172.

16. De Kouchkovsky and Abdul-Hay M. Acute Myeloid Leukemia : a Comprehensive Review and 2016 Update. Blood cancel Journal. 2016; 6:1-10.

17. Jiang F, Fernandez D, Church J, Gulati R, Taylor A, Menon M, Kurikose P. Correlation between Peripheral Blood Counts and Day 14 Bone Marrow Biopsy in Acute Myeloid Leukemia during Induction Chemotherapy. Blood. 2015; 126:4894-97.

18. Pertiwi NMI, Niruri $R$, \& Ariawati $K$. Gangguan Hematologi Akibat Kemoterapi pada Anak dengan Leukemia Limfoblastik Akut di Rumah Sakit Umum Pusat Sanglah, Bali. Jurnal Farmasi Udayana. 2013.

19. Alvarnas JC, et al. Acute Lymphoid Leukemia. Natl Comprehens Cancer Netw. 2015; 13:1240-1279.

20. Ha CS, Michalek JE, Elledge $R$, et al. p53-Based Strategy to Reduce Hematological Toxicity of Chemotherapy: A Proof of Principle Study. Mol Oncol. 2016; 10(1):148156.

21. Apostolidis PA, Woulfe DS, Chavez M, Miller WM, Papoutsakis ET. Role of Tumor Suppressor p53 in Megakaryopoiesis and Platelet Function. Exp Hematol. 2012; 40(2):131-142.

22. Zhang $\mathrm{Y}$, Chen $\mathrm{H}$, Zhou S, Wang $\mathrm{S}$, et al. Sp1 and c-Myc Modulate Drug Resistance of Leukemia Stem Cells by Regulating Survivin Expression through the ERK-MSK MAPK Signaling Pathway. Mol Cancer. 2015; 14:56. 